\title{
Analisa Algoritma Raita pada Automatic Hyperlink
}

\author{
Guidio Leonarde Ginting \\ STMIK Budi Darma \\ Jl. Sisingamangaraja No. 338, Medan - Sumatera Utara, (061) 7875998 \\ guidio.leonard626@gmail.com
}

\begin{abstract}
Today the development of technology is very rapidly developing which affects various aspects of life. The development of these technologies takes on several important roles such as business, organizational structure and organizational management. The website is a form of information technology development that presents information needed by all people in carrying out their activities such as business, social, and others. Hyperlink is a way that is used to connect a part of a website in the form of files, documents, images or so on. Arranging the appearance of interfaces that are user friendly from a website is important because if a website has so many menus, it will be difficult for someone to move from one page to another. If the menu presentation is not appropriate then indirectly it will reduce user friendly value. One way that can be done is to apply automatic hyperlinks, namely if an information that is conveyed on a page contains words that match the other information pages, it will automatically make the word into a menu. To be able to apply the automatic hyperlink, an algorithm is needed to find the words contained in a paragraph, one of the algorithms that can be used is the Raita algorithm. Raita algorithm is part of the exact string matching algorithm, which is to match the string correctly with the arrangement of characters in a matched string that has the number or sequence of characters in the same string.
\end{abstract}

Keywords : Automatic Hyperlink, Raita, String Matching

\begin{abstract}
Abstrak-Dewasa ini perkembangan teknologi sangat berkembang pesat yang mempengaruhi berbagai aspek kehidupan, Perkembangan teknologi tersebut mengambil beberapa peran penting seperti bisnis, struktur organisasi dan manajemen organisasi. Website merupakan salah satu bentuk dari perkembangan teknologi informasi yang menyajikan informasi yang dibutuhkan oleh seluruh masyarakat dalam melakukan kegiatannya seperti bisnis, sosial, dan lainnya. Hyperlink merupakan suatu cara yang digunakan untuk menghubungkan suatu bagian dari website baik berupa file, dokumen, gambar atau lain sebagainya. Menata tampilan interface yang bersifat user friendly dari suatu website merupakan hal yang penting karena jika sebuah website yang memiliki begitu banyak menu, akan mempersulit seorang dalam berpindah dari suatu halaman ke kehalaman lain. Jika penyajian menu tersebut tidak sesuai maka secara tidak langsung akan mengurangi nilai user friendly. Salah satu cara yang dapat dilakukan adalah dengan menerapkan automatic hyperlink yaitu jika suatu informasi yang disampaikan pada suatu halaman mengandung kata yang sesuai dengan halaman informasi lainnya maka secara otomatis akan menjadikan kata tersebut menjadi menu. Untuk dapat menerapkan automatic hyperlink tersebut, dibutuhkanlah suatu algoritma untuk menemukan kata yang terdapat pada suatu paragraf, salah satu aloritma yang dapat digunakan adalah agoritma Raita. Algoritma Raita merupakan bagian dari algoritma exact string matching yaitu pencocokan string secara tepat dengan susunan karakter dalam string yang dicocokkan memiliki jumlah maupun urutan karakter dalam string yang sama.
\end{abstract}

Kata Kunci : Automatic Hyperlink, Raita, String Matching 


\section{PENDAHULUAN}

Dewasa ini perkembangan teknologi sangat berkembang pesat yang mempengaruhi berbagai aspek kehidupan seperti pendidikan, ekonomi, kesehatan, sosial budaya dan lain sebagainya. Perkembangan teknologi tersebut mengambil beberapa peran penting seperti bisnis, struktur organisasi dan manajemen organisasi. Disisi lain perkembangan teknologi juga memberikan peranan yang besar dalam pengembangan teknologi informasi, dimana perkembangan teknologi informasi telah menggantikan media cetak menjadi media online serta menawarkan banyak kelebihan yang tidak ditemukan pada media cetak. Website merupakan suatu media online dan salah satu bentuk dari perkembangan teknologi informasi yang menyajikan informasi yang dibutuhkan oleh seluruh masyarakat dalam melakukan kegiatannya seperti bisnis, sosial, dan lainnya. Pada dasarnya website merupakan suatu halaman yang memuat suatu informasi yang dibuat dengan tujuan tertentu dan saling terhubung dengan lainnya secara luas namun kehadiran website dalam masyarakat sangat mempengaruhi kehidupan masyarakat sehari-hari, karena masyarakat dapat dengan mudah mendapatkan informasi yang dibutuhkan hanya dengan menghubungkan perangkat komputer ke dalam jaringan internet. Hyperlink merupakan suatu cara yang digunakan untuk menghubungkan suatu bagian dari website baik berupa file, dokumen, gambar atau lain sebagainya pada suatu website lainnya. Tujuan dari hyperlink yaitu untuk memudahkan pengguna website untuk menjelajahi berbagai halaman terkait informasi yang disajikan.

Pada dasarnya hyperlink merupakan suatu fungsi HTML (Hyper Text Markup Language) yang bertujuan menyediakan jalan pintas kepada pembaca menuju informasi lainnya[5]. Pada sebuah website hyperlink dapat terlihat dan digunakan melalui sebuah kata atau kalimat yang disusun dengan sedemikian rupa dan jika diklik akan menampilkan halaman lain, kata atau kalimat tersebut biasa disebut dengan menu. Menata tampilan interface yang bersifat user friendly dari suatu website merupakan hal yang penting karena jika sebuah website yang memiliki begitu banyak menu, akan mempersulit seorang dalam berpindah dari suatu halaman ke kehalaman lain jika penyajian menu tersebut tidak sesuai dan secara tidak langsung akan mengurangi nilai user friendly dari website tersebut. Penempatan menu dan informasi sering sekali menjadi masalah serius yang dihadapi seorang perancang website, jika menu yang ditampilkan banyak dan informasi yang ditampilkan juga detail serta ditampilkan pada area yang terbatas[6]. Oleh sebab itu dibutuhkan suatu teknik untuk menampilkan menu dan informasi tersebut namun tidak mengurangi nilai user friendly dari website dari sebuah website. Salah satu cara yang dapat dilakukan adalah dengan menerapkan automatic hyperlink yaitu jika suatu informasi yang disampaikan pada suatu halaman mengandung kata yang sesuai dengan halaman informasi lainnya maka secara otomatis akan menjadikan kata tersebut menjadi menu, dengan demikian menu berada pada area informasi namun tidak menghilangkan fungsi sebagai bagian dari informasi. Untuk menghubungan sebuah halaman website dengan suatu halaman website lainnya melalui kata yang terdapat dalam suatu paragraf atau lebih, dibutuhkanlah suatu algoritma untuk menemukan kata atau kalimat yang terdapat pada suatu paragraf, salah satu aloritma yang dapat digunakan adalah agoritma Raita. Algoritma Raita merupakan bagian dari algoritma exact 
string matching yaitu pencocokan string secara tepat dengan susunan karakter dalam string yang dicocokkan memiliki jumlah maupun urutan karakter dalam string yang sama. [1]

\section{METODOLOGI PENELITIAN}

\subsection{Kerangka Penelitian}

Metodologi penelitian ini digambarkan dalam bentuk kerangka kerja (framework). Kerangka kerja merupakan struktur konseptual dasar yang digunakan untuk memecahkan atau menangani suatu masalah yang kompleks. Berdasarkan pedoman dari langkah kerja inilah penelitian akan dilakukan.

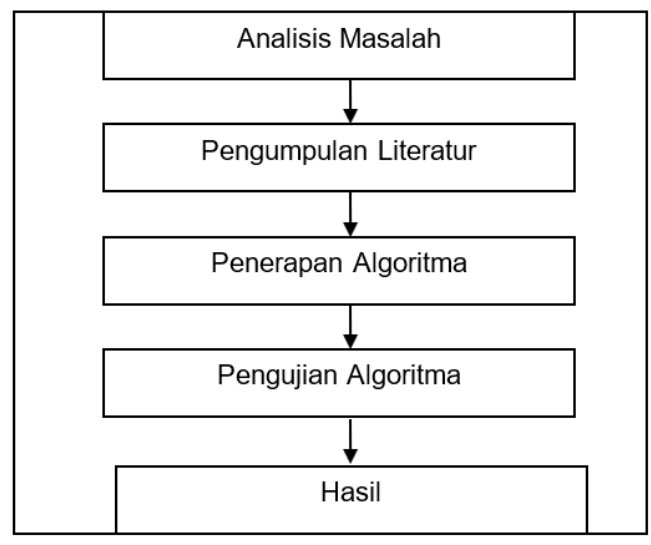

Gambar 1. Kerangka Kerja

\subsection{Website dan HyperLink}

Website atau situs dapat diartikan sebagai kumpulan halaman yang menampilkan informasi data teks, data gambar diam atau gerak, data animasi, suara, video dan atau gabungan dari semuanya, baik yang bersifat statis maupun dinamis yang membentuk satu rangkaian bangunan yang saling terkait dimana masing-masing dihubungkan dengan jaringan-jaringan halaman (hyperlink) [2].

Secara terminologi, website adalah kumpulan dari halaman-halaman situs, yang biasanya terangkum dalam sebuah domain atau subdomain, yang tempatnya berada di dalam World Wide Web(WWW) di Internet. Sebuah halaman web adalah dokumen yang ditulis dalam format HTML (Hyper Text Markup Language), yang hampir selalu bisa diakses melalui HTTP, yaitu protokol yang menyampaikan informasi dari server website untuk ditampilkan kepada para pemakai melalui web browser. Semua publikasi dari website-website tersebut dapat membentuk sebuah jaringan informasi yang sangat besar [3]. Halaman-halaman dari website akan bisa diakses melalui sebuah URL yang biasa disebut Homepage. URL ini mengatur halaman-halaman situs untuk menjadi sebuah hirarki, meskipun, hyperlink-hyperlink yang ada di halaman tersebut mengatur para pembaca dan memberitahu sususan keseluruhan dan bagaimana arus informasi berjalan. Untuk membangun sebuah website dibutuhkan serangkaian script atau code tertentu yang berasal dari bahasa pemrograman tertentu, seperti PHP, JSP, ASP, Ruby dan lain sebagainya. 


\subsection{Raita}

Algoritma Raita merupakan bagian dari algoritma exact string matching yaitu pencocokan string secara tepat dengan susunan karakter dalam string yang dicocokkan memiliki jumlah maupun urutan karakter dalam string yang sama. Raita merancang sebuah algoritma dengan membandingkan karakter yang terakhir dari pola darikarakter paling kanan dari window. Jika mereka cocok, kemudian karakter pertama dari pola teks paling kiri dari window juga dibandingkan. Jika mereka cocok, maka akan dibandingkan karakter tengah pola dengan karakter teks tengah window. Pada akhirnya, jika mereka benar-benar cocok, maka algoritma membandingkan karakter lain mulai dari karakter kedua ke karakter kedua terakhir, dan mungkinmembandingkan dengan karakter tengah lagi [2].

Kebanyakan algoritma pencocokan string terdiri dari fese preprocessing dan fase pencarian. Tahap preprocessing menganalisis karakter dalam pola untuk menggunakan informasi ini untuk menentukan pergeseran pola dalam kasus ketidakcocokan atau seluruh pencocokan, dengan tujuan mengurangi jumlah perbandingan karakter, sedangkan fase pencarian mendefinisikan urutan perbandingan karakter dalam setiap upaya antara pola dan teks [3]. Pada algoritma raita terdiri atas 2 fase, yaitu :

a. Fase Preprocessing

Fase preprocessing pada algoritma Raita terdiri dari penghitungan fungsi pergeseran bad-character dari algoritma Boyer Moore. Bad-character merupakan kumpulan karakter yang mewakili pola (pattern). Fungsi pergeseran bad-character dari algoritma Boyer Moore ini disimpan pada tabel bmBc. Untuk membuat tabel bmBc maka dapat menggunakan persamaan sebagai berikut

$$
\operatorname{bmBc}[\mathrm{x}[\mathrm{i}]=\mathrm{m}-\mathrm{i}-1]
$$

\section{b. Face Pencarian}

Tahap pencarian algoritma Raita:

1. Jika dalam proses pembandingan terjadi ketidakcocokan antara pasangan karakter pada akhir pola dengan karakter teks, pergeseran dilakukan sesuai nilai karakter pada tabel BmBc.

2. Jika dalam proses pembandingan akhir pola terjadi ketidakcocokan lagi maka karakter akan digeser lagi sesuai tabel BmBc.

3. Jika karakter akhir pola dengan karakter pada teks yang sedang dibandingkan cocok, maka posisi karakter pada pola dan teks akan memiliki nilai (0), dan dilanjutkan pencocokan pada karakter awal pola. Jika cocok maka dilanjutkan pencocokan dengan karakter tengah pola.

4. Jika akhir, awal dan tengah pola telah cocok. Pencocokan dilanjutkan dengan bagian kanan dari awal karakter pada pola, jika cocok maka dicocokkan pada bagian kanan tengah pola 


\title{
3. HASIL DAN PEMBAHASAN
}

\subsection{Analisa Algoritma Raita}

Yang menjadi objek pada penelitian ini adalah sebuah website yang terdiri dari beberapa halaman dan setiap halaman terdiri dari beberapa paragraf.
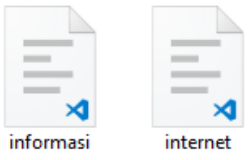

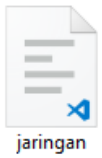

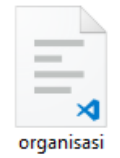

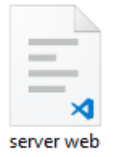

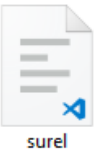
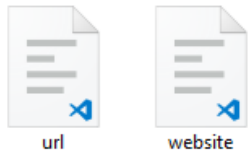

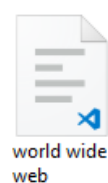

Gambar 2. File halaman website

\begin{abstract}
Situs web (bahasa Inggris: website) adalah sekumpulan halaman web yang saling berhubungan yang umumnya berada pada peladen yang sama berisikan kumpulan informasi yang disediakan secara perorangan, kelompok, atau organisasi. Sebuah situs web biasanya ditempatkan setidaknya pada sebuah server web yang dapat diakses melalui jaringan seperti Internet, ataupun jaringan wilayah lokal (LAN) melalui alamat Internet yang dikenali sebagai URL. Gabungan atas semua situs yang dapat diakses publik di Internet disebut pula sebagai World Wide Web atau lebih dikenal dengan singkatan WWW. Meskipun setidaknya halaman beranda situs Internet umumnya dapat diakses publik secara bebas, pada praktiknya tidak semua situs memberikan kebebasan bagi publik untuk mengaksesnya, beberapa situs web mewajibkan pengunjung untuk melakukan pendaftaran sebagai anggota, atau bahkan meminta pembayaran untuk dapat menjadi aggota untuk dapat mengakses isi yang terdapat dalam situs web tersebut, misalnya situs-situs yang menampilkan pornografi, situs-situs berita, layanan surel (e-mail), dan lain-lain. Pembatasan-pembatasan ini umumnya dilakukan karena alasan keamanan, menghormati privasi, atau karena tujuan komersial tertentu.
\end{abstract}

Gambar 3. Sampel paragraf dari sebuah file halaman website

Selanjutkan dilakukan penerapan algoritma Raita dalam melakukan automatic hyperlink pada sampel paragraf diatas. Sebelum melakukan penerapan algoritma raita maka untuk mendapatkan pattern diambil dari nama file dari halaman website, maka akan didapatkan pattern "informasi, internet, jaringan, organisasi, server web, surel, peladen, url, website, world wide web". Setelah didapatkan patern tersebut maka selanjutnya akan dilakukan perbandingan dengan suatu paragraf. Untuk memudahkan proses pencocokan pattern dengan paragraf diatas maka pisahkan setiap kata pada pattern sebelum dilakukan proses pencarian. Untuk melakukan proses pencarian, maka langkah-langkah yang dilakukan sebagai berikut :

a. Fase Preprosessing

Sebelum melakukan proses pencarian, maka terlebih dahulu dilakukan proses pembentukan tabel bmBc dengan persamaan

$\operatorname{bmBc}[\mathrm{x}[\mathrm{i}]=\mathrm{m}-\mathrm{i}-1]$

text :website adalah sekumpulan halaman pada peladen yang berisikan kumpulan informasi

pattern : peladen

Tabel 1. Tabel bmBc peladen 


\section{bmBc $[\mathrm{p}]=7-0-1=6$ \\ $\mathrm{bmBc}[\mathrm{e}]=7-1-1=5$ \\ bmBc $[1]=7-2-1=4$ \\ $\mathrm{bmBc}[\mathrm{a}]=7-3-1=3$ \\ $\mathrm{bmBc}[\mathrm{d}]=7-4-1=2$ \\ bmBc[n]=7-5-1=1}

berikut:

Berdasarkan tabel diatas, dapat diketahui perhitungan tabel bmBc sebagai

${ }^{*}$ ) karakter yang tidak dikenali

Panjang pola pada pattern internet adalah 7, maka untuk karakter yang tidak terdapat pada tabel nilainya 7 .

b. Fase pencarian

Proses pencocokan pattern dengan teks diawali dengan kiri teks, seperti pada gambar dibawah ini :

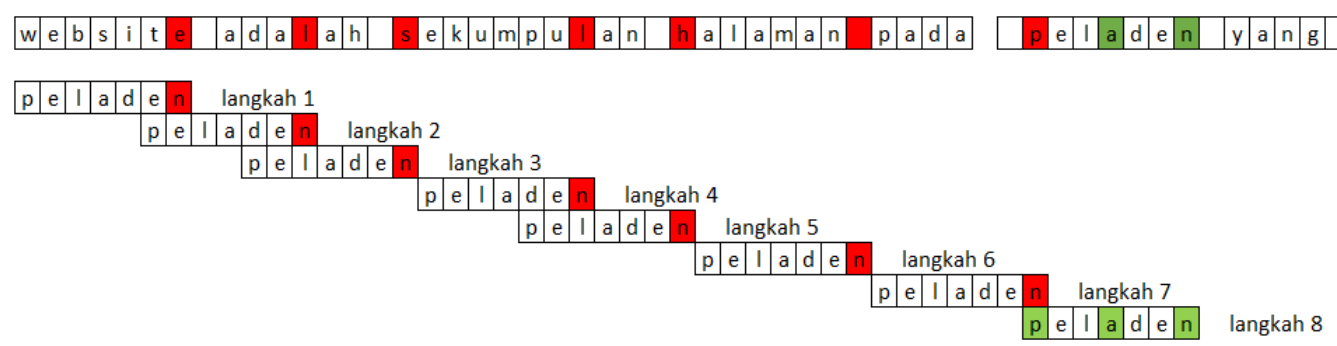

Gambar 4. Langkah-langkah Pencarian pada teks

Dari gambar 3 diatas dapat diketahui langkah-langkah pencarian pattern pada text sebagai berikut :

1. Langkah 1

Terjadi ketidakcocokan antara karakter "e" dengan " $\mathrm{n}$ ", karena karakter "e" terdapat pada pattern maka pergeseran selanjutnya berdasarkan tabel bmBc karakter "e" yaitu sebanyak 5, maka pergeseran pattern sebanyak 5.

2. Langkah 2

Terjadi ketidakcocokan antara karakter "l" dengan "n", karena karakter "l" terdapat pada pattern maka pergeseran selanjutnya berdasarkan tabel bmBc karakter "l" yaitu sebanyak 4, maka pergeseran pattern sebanyak 4.

3. Langkah 3

Terjadi ketidakcocokan antara karakter "s" dengan "n", karena karakter " $n$ " tidak terdapat pada pattern maka diwakilkan dengan karakter *, maka pergeseran selanjutnya berdasarkan tabel bmBc karakter "*” yaitu sebanyak 7, maka pergeseran pattern sebanyak 7 . 


\section{Langkah 4}

Terjadi ketidakcocokan antara karakter "l" dengan "n", karena karakter "l" terdapat pada pattern maka pergeseran selanjutnya berdasarkan tabel bmBc karakter "l" yaitu sebanyak 4, maka pergeseran pattern sebanyak 4.

5. Langkah 5

Terjadi ketidakcocokan antara karakter " $h$ " dengan " $n$ ", karena karaktek " $h$ " tidak terdapat pada pattern maka diwakilkan dengan karakter “*”, maka pergerseran selanjutnya berdasarkan tabel bmBc karakter “*” sebanyak 7, sehingga pergeseran pattern sebanyak 7 .

6. Langkah 6

Terjadi ketidakcocokan antara karakter "spasi" dengan "n", karena karakter "spasi" tidak terdapat pada pattern maka diwakilkan dengan karakter “*”, maka pergeseran selanjutnya berdasarkan tabel bmBc karakter “*” sebanyak 7, sehingga pergeseran pattern sebanyak 7 .

7. Langkah 7

Terjadi ketidakcocokan antara karakter " $p$ " dengan " $n$ ", karena karakter " $p$ " terdapat pada pattern maka pergeseran selanjutnya berdasarkan tabel bmBc karakter "p" sebanyak 6, maka pattern bergeser sebanyak 6.

8. Langkah 8

Terjadi kecocokan antara karakter " $n$ " pada text dengan karakter " $\mathrm{n}$ " pada pattern" sehingga selanjutkan dibandingkan karakter awal pattern yaitu karakter " $p$ " pada text dengan karakter " $p$ " pada pattern dan terjadi kecocokan, sehingga dilakukan perbandingkan karakter ditengah pettern dan terjadi kecocokan.

\subsection{Pengujian}

Pada penelitian ini dilakukan beberapa pengujian dengan melakukan pencarian dari berbagai pattern terhadap sampel paragraf pada gambar 2. Hasil pengujian pattern tersebut dapat dilihat pada tabel 3 dibawah ini :

Tabel 2. Hasil Pengujian

\begin{tabular}{|l|l|l|l|l|}
\hline No & Pattern & Running Time & Total Link & Hasil \\
\hline 1 & Informasi & 0,265 & 1 & Match \\
\hline 2 & Internet & 0,215 & 3 & Match \\
\hline 3 & Jaringan & 0,225 & 2 & Match \\
\hline 4 & Organsasi & 0,271 & 1 & Match \\
\hline 5 & Server Web & 0,201 & 1 & Match \\
\hline 6 & Surel & 0,192 & 1 & Match \\
\hline 7 & url & 0,382 & 1 & Match \\
\hline 8 & Website & 0,292 & 1 & Match \\
\hline 9 & World wide web & 0,182 & 1 & Match \\
\hline 10 & Peladen & 0,273 & 1 & Match \\
\hline
\end{tabular}


website adalah website adalah sekumpulan halaman pada peladen yang berisikan kumpulan informasi yang disediakan secara perorangan, kelompok, atau organisasi. Sebuah situs web biasanya ditempatkan setidaknya pada sebuah server web yang dapat diakses melalui jaringan seperti Internet, ataupun jaringan wilayah lokal (LAN) melalui alamat Internet yang dikenali sebagai URL. Gabungan atas semua situs yang dapat diakses publik di Internet disebut pula sebagai World Wide Web atau lebih dikenal dengan singkatan WWW. Meskipun setidaknya halaman beranda situs Internet umumnya dapat diakses publik secara bebas, pada praktiknya tidak semua situs memberikan kebebasan bagi publik untuk mengaksesnya, beberapa situs web mewajibkan pengunjung untuk melakukan pendaftaran sebagai anggota, atau bahkan meminta pembayaran untuk dapat menjadi aggota untuk dapat mengakses isi yang terdapat dalam situs web tersebut, misalnya situs-situs yang menampilkan pornografi, situs-situs berita, layanan surel (e-mail), dan lain-lain. Pembatasan-pembatasan ini umumnya dilakukan karena alasan keamanan, menghormati privasi, atau karena tujuan komersial tertentu.

Gambar 5. Hasil Automatic Hyperlink

Berdasarkan hasil pengujian yang dilakukan pada tabel 2 diatas membuktikan bahwa algoritma Raita berhasil mendeteksi kata atau kalimat berdasarkan pattern yang telah ditentukan.

\section{KESIMPULAN}

Berdasarkan penelitian yang telah dilakukan maka kesimpulan yang dapat diambil adalah sebagai berikut :

a. Algoritma Raita dapat digunakan untuk melakukan pencarian teks atau kata dari suatu paragraf.

b. Algoritma Raita masih dapat melakukan pencarian teks atau kata yang terdiri dari beberapa paragraf.

c. Kecepatan proses pencocokan pattern dengan text tergantung dari panjang karakter pattern yang digunakan, semakin panjang karakter pattern maka semakin cepat proses pencocokan dan sebaliknya.

\section{DAFTAR PUSTAKA}

[1] Nasution, N. 2016. Implementasi Algoritma Raita Dalam Kamus Bahasa Indonesia-Mandailing Berbasis Android. Skripsi. Medan. Universitas Sumatera Utara

[2] Hartono, H. 2014. Pengertian Website dan Unsur-Unsurnya. Jurnal Ilmu Teknologi Informasi. 27

[3] Klaib, A. F. \& Osborne, H. 2009.BRQS Matching Algorithm for Searching ProteinSequence Databases. International Conference on Future Computer and Communication: 223-226

[4] Charras, C. \& Lecroq, T. 1997. Handbook ofExact String Matching Algorithms.OxfordUniversity Press: United Kingdom

[5]R. A.S dan M. Shalahuddin, Rekayasa Perangkat Lunak. Yogyakarta: Modula, 2011.

[6]R. Sarno, Y. Anistyasari, dan R. Fitri, Semantic Search. Yogyakarta: Andi, 2012. 